\title{
Technical and Economic Assessment of Local Power Supply Systems for Agro-Industrial Production in the Digital Economy
}

\author{
Vladimir T. Vodyannikov ${ }^{1}$, Elena V. Khudyakova ${ }^{1}$, Marat M. Nizamutdinov $^{2, *}$, Asiya K. Subaeva ${ }^{2}$, Ilnur N. Safiullin $^{2}$ \\ ${ }^{1}$ Russian State Agrarian University-MTAA named after K. A. Timiryazev, Moscow, Russia \\ ${ }^{2}$ Kazan State Agrarian University, Kazan, Russia
}

\begin{abstract}
Energy and energy supply development determines the rate of production intensification, including agricultural production. The current state of rural power supply is characterized by a high degree of deterioration of electrical equipment, long distance overhead power lines, low reliability of low-voltage electrical networks, and a higher accident rate. With an aim of ensuring food security and export orientation of the industry for the next 5 years, it is necessary to implement a set of measures to improve the efficiency of energy supply to agricultural production. This task will be hampered by a constant rise in prices and tariffs for energy resources. Thus, over the last 20 years, energy costs have increased from 3-5\% to 30-40 $\%$ in agricultural production. The specific capital investment (per $1 \mathrm{~kW}$ of power) and the cost of $1 \mathrm{kWh}$ of electricity were reported to depend on a type of local energy source and its capacity. The paper proposes a method for marking out the economic boundaries of the effective use of local power supply arrangements to replace a standard central station. A power gen-set supplying energy to an agricultural holding is capable of operating in two modes subsequent upon utility (central station) electricity - autonomous and parallel. The authors compared the cost of electrical and thermal energy produced by the power gen-set and tariffs for these types of energy. Calculations have shown that it is advisable for an agricultural holding to have a local power supply system being a power gen-set based on gas engine-generators.
\end{abstract}

\section{Introduction}

At present, in the national economy as such and in the farming industry in particular, fuel and energy are perceived not only as material and technical resources, but also as a factor that has a significant impact on the rates of social and economic development of regions and the country at large. In the modern world, the level of development of energy and energy supply determines labor productivity, food security, and, ultimately, the security of the state as a whole [7]. Numerous statistical data indicate that in developed countries an increase in agricultural production by $1 \%$ is achieved not only due to energy savings, but is accompanied by growing energy costs in agriculture by $2-3 \%$. In other words, increasing food production has a strong energy component.

Today, energy intensity of production in the farming industry acts as a measure to ensure competitive strength of produce. The country has an overestimated energy intensity of agricultural production (4-6 times higher than in the EU) and, as a result, a high fuel and energy component in the cost of the industry (13-35\%, in the EU - $10 \%$ ) (Table 1). The rate of labor productivity in domestic agriculture is only $10 \%$ of that in the United States where the energy-to-labor ratio is 3-4 times higher $[9,10]$.
Table 1. Energy intensity of agricultural production (on average for Russia)

\begin{tabular}{|c|c|c|c|}
\hline Product type & $\begin{array}{c}\text { Reference } \\
\text { fuel } \\
\text { consumption } \\
\text { for } \\
\text { agricultural } \\
\text { products, } \\
\text { kg/c }\end{array}$ & $\begin{array}{c}\text { Reference } \\
\text { fuel } \\
\text { consumption } \\
\text { for } \\
\text { agricultural } \\
\text { products, } \\
\text { kg/ths. RUB }\end{array}$ & $\begin{array}{c}\text { Share of } \\
\text { energy costs } \\
\text { in the prime } \\
\text { cost of } \\
\text { agricultural } \\
\text { production, } \\
\text { \% }\end{array}$ \\
\hline Grain crops & 13.0 & 13.5 & 32.5 \\
\hline Milk & 21.7 & 12.0 & 30.0 \\
\hline Pork & 208.0 & 12.2 & 32.5 \\
\hline Beef & 94.0 & 6.0 & 13.0 \\
\hline Eggs (1000 pcs.) & 36.0 & 12.0 & 35.0 \\
\hline
\end{tabular}

Today, one of the priorities for energy development inside the farming industry is to establish a sustainable and efficient power supply system with lower energy intensity of production and, consequently, its cost, and to create enabling social and living conditions in rural areas.

The current state of rural energy supply to the farming industry can be characterized as follows:

- long distance overhead power lines and low efficiency of outdated rural energy supply arrangements, hundreds of thousands of kilometers of worn out lines and electrical substations;

\footnotetext{
Corresponding author: marat181@ rambler.ru
} 
- unreliability of low-voltage electrical networks;

- a steadily growing accident rate in the networks up to 20 outages per $100 \mathrm{~km}$, the duration of the failure to supply electricity reaches up to 250 hours per year;

- unreasonable electricity tariffs for rural consumers, the cost of electricity for agricultural producers is 1.5-2.0 times higher than for manufacturing enterprises [8];

- it is not clearly defined who is responsible for rural power grids, with most of them to be abandoned, which has negative implications for their operation. There is an urgent need to develop and implement a targeted Program for the restoration of ownerless unexploited rural electrical networks;

- outdated designs of overhead power transmission lines and electrical substations 10(6)-0.4 kV, operated beyond the amortization life; up to $70 \%$ of $0.4 \mathrm{kV}$ overhead power lines and about $60 \%$ with a voltage of $6-10 \mathrm{kV}$ have $100 \%$ wear and should be taken out of service, resulting in frequent power outages to rural consumers, voltage deviation is $10-20 \%$, which significantly exceeds the GOST standard $( \pm 5 \%)$, electricity losses in rural power grids reach $30-35 \%$ (at a rate of 5-7\%);

- there is almost no demand for nonconventional and renewable power sources that are often more efficient for remote rural consumers; in its embryonic state, the development of efficient systems and equipment for the generation of electricity and heat, in particular, from crop and livestock waste; the use of nonconventional and sustainable energy sources in the energy balance of the village does not exceed $2-2.5 \%$, which is much less than in leading countries [1-3];

- against the background of low energy efficiency of agricultural production, there is a shortage of qualified personnel, less than $50 \%$ employed, which contributes to worsened maintenance of the energy sector; there are no adequate power service staff at agricultural enterprises, which causes electrical injuries to workers and animals.

Along with excessive wear of equipment and communications, in addition to energy shortfalls, the energy sector steadily increases prices and tariffs for energy resources exploited in the farming industry, which overestimates the cost of agricultural production and lowers its competitiveness.

Due to some negative trends in the availability of utility (central station) electricity to large farming holdings that exploit innovative technologies and equipment based on digitalization means, alternative methods of energy supply are being sought. The most important thing to call for by agricultural holdings is reliable energy supply with modern innovations being integrated in animal husbandry, poultry farming, greenhouse vegetable growing, storage and processing of agricultural products.

In a real-case scenario, in the conditions of existing agricultural production, there are many ways of solving this task. For example, by installing and starting a backup power supply or main local self-supply. Given that all rural consumers have a centralized power supply, a question comes up as to by what means a certain option of power supply will be economically viable, or rather, whether centralized or local (decentralized) power supply is economically viable.

The specific capital investment (per $1 \mathrm{~kW}$ of power) and the cost of $1 \mathrm{~kW} \cdot \mathrm{h}$ of electricity depend on the type of local energy source, its capacity, the fuel component in the cost of electricity generation, as well as on the level of reliability of power supply (that affects the extent of damage to property from power cuts).

In the 20-30s of the last century, the power base of the village was represented by a network of small power plants of various types. Intensive mass construction of small hydroelectric power plants began during the period of restoration of the national economy destroyed by the war. In the $60 \mathrm{~s}$, rural power plants provided up to $50 \%$ of the electricity. Later, the state energy policy towards small rural energy changed. Thus, by the end of the 70s, more than $90 \%$ of rural power plants with a capacity of up to $100 \mathrm{~kW}$ were closed down, ostensibly on inefficiency grounds $[4,5]$.

At present the situation has changed dramatically. The prices and tariffs for fuel and energy resources have increased, in the cost of agricultural production, energy costs have increased from $3-5$ to $30-40 \%$, close attention is paid to environmental issues, carbon dioxide emissions, etc.

\section{Methods}

In light of the above, today the most vital priority is the development of small rural energy. It is necessary to mark out the economic boundaries of the effective use of local power supply arrangements to replace a standard central station. In other words, the value of the tariff for electricity received from the power system should be economically justified, making allowance for capital investments for the reconstruction of the central power system supplying the farming industry, which provides the most efficient power supply source. The proposed method will identify an opportunity of receiving or not receiving, at an approved tariff for electricity from the power system, savings from the implementation of a local power supply system in such an amount that the calculated (actual) economic efficiency of capital investments $(E a)$ in the infrastructure of the local system will exceed a regulatory standard $(E s)$ :

$$
E a=(T e \cdot Q e-C G l e) /(I l-I r),
$$

where $T e$ is the tariff for electricity from the power system, rubles/kWh; $Q e$ is the volume of consumed electricity, $\mathrm{kWh}$; CGle is the costs of electricity generation in the local power supply system, rubles; $I l$ is the investment in the local power supply system, rubles; $I r$ is the investment in the reconstruction of the central power supply system, rubles.

If, when comparing power supply options $\mathrm{Te} \cdot \mathrm{Qe}>$ CGle, and Il $<$ Ir, then the local power supply should be preferred, provided that $\mathrm{Te} \cdot \mathrm{Qe}<\mathrm{CGle}$ - the central power supply should be recognized as effective, i.e. from the power system. Transforming the above condition and establishing that $\mathrm{Es}=\mathrm{Ea}$, we get:

$$
\text { Es(Il-Ir) }=\text { Te*Qe }- \text { CGle }
$$


or

$$
(\mathrm{CGle}+\mathrm{Es}(\mathrm{Il}-\mathrm{Ir}) / \mathrm{Qe}=\mathrm{Te}
$$

When both the tariff for electricity from the power system and the cost of electricity generation from a local source are known, the condition for justifying the choice of the power supply option is reduced to the calculation by the formula:

$$
\mathrm{Ea}=(\mathrm{Te}-\mathrm{Sle}) /(\mathrm{Isl} \text { Isr })>\mathrm{Es}
$$

where Sle is the cost of producing $1 \mathrm{kWh}$ of electricity in the local system, rubles/kWh; Isl and Isr are specific capital investments in the local system and reconstruction of the central power supply, rubles/kWh.

Based on their inequality (3), it is possible to determine the maximum value of the production cost of $1 \mathrm{kWh}$ of electricity in the local power supply at a given tariff (Te). This condition will look like:

$$
\text { Sle }<\text { Te - Es(Isl - Isr) }
$$

To achieve objective comparison of the options for energy supply systems, it is necessary to ensure compliance with the energy comparability of options:

- each of the options is imperative to provide for the use of modern technical means and systems. Calculations must be made under the optimal operating conditions of the equipment in the compared versions;

- providing an equivalent energy effect;

- ensuring an equal degree of reliability of power supply;

- the compared options are designed to meet the environmental requirements and labor protection, including sanitary and hygienic requirements;

- calculations should be made in uniform prices for energy resources, equipment, and other material resources, through a single regulatory framework.

\section{Results}

A local power supply system based on a gas enginegenerator used at the AgroPromkomplektatsiya Holding proved to be economically advantageous and expedient as confirmed by performance indicators. In 2012 in Tver region, an autonomous power gen-set geared for the production of electrical and thermal energy for the own needs of the AgroPromkomplektatsiya with a capacity of 3 MW was commissioned based on Jenbacher gas engine-generators: 3 units of $1 \mathrm{MW}$ each.

The power gen-set is a mini-heat and power plant (mini-HPP). The GEG works such that two resources are generated simultaneously - electrical and thermal energy (cogeneration process). The units provide an additional resource - cooling (trigeneration). The central principle of gas engine-generators is such that gas fuel of certain parameters is supplied to a gas engine. During the combustion process mechanical energy is generated, which is converted by an electric generator into electrical energy. The latter is supplied to consumers via the local power line. Heat exchangers are used to recover heat energy into the heating network.

Subsequent upon utility (central station) electricity, the power gen-set is capable of operating in several modes: autonomous mode (external networks are absent or disconnected), power supply from the power gen-set (parallel mode - the power gen-set operates in parallel with the external network); power is supplied from two sources simultaneously. The technical characteristics of the Jenbacher GG (one unit) installed at the target power gen-set are presented in Table 2. The overall efficiency is rather high making up $86.6 \%$.

Table 2. Technical characteristics of Jenbacher gas enginegenerator

\begin{tabular}{|c|c|c|}
\hline Index & $\begin{array}{c}\text { Unit of } \\
\text { measurement }\end{array}$ & Value \\
\hline Fuel energy supplied & $\mathrm{kW}$ & 2.605 \\
\hline Natural gas consumption & $\mathrm{Nm}^{3} / \mathrm{hour}$ & 274 \\
\hline Output electric power & $\mathrm{kW}$ & 1.063 \\
\hline Useful heat output & $\mathrm{kW}$ & 1.193 \\
\hline Total power output & $\mathrm{kW}$ & 2.256 \\
\hline Electrical efficiency & $\%$ & 40.8 \\
\hline Heat efficiency & $\%$ & 45.8 \\
\hline Overall efficiency & $\%$ & 86.6 \\
\hline
\end{tabular}

The main consumer of energy supplied from the power gen-set is the Dmitrogorsk meat processing plant that is part of the agricultural holding and one of the largest and most high-tech enterprises in Tver region. The AgroPromkomplektatsiya Holding is the most dynamically developing vertically integrated holding with a full closed cycle for the production of meat and dairy products. The energy consumption parameters of the Dmitrogorsk meat processing plant are presented in Table 3.

\begin{tabular}{|c|c|c|c|c|}
\hline \multirow[t]{2}{*}{ Index } & \multicolumn{4}{|c|}{ Years } \\
\hline & 2017 & 2018 & 2019 & 2019 in \% \\
\hline $\begin{array}{c}\text { Meat production } \\
\text { volume of products, } t\end{array}$ & 17.017 & 17.882 & 17.932 & $\begin{array}{l}2.017 \\
105.4\end{array}$ \\
\hline $\begin{array}{l}\text { Food marketing bill, } \\
\text { mln. RUB }\end{array}$ & 3.526 .8 & 3.803 .6 & 3.872 .1 & 109.8 \\
\hline $\begin{array}{l}\text { Electricity } \\
\text { consumption, total, } \\
\text { ths. kWh, including } \\
\text { own production: } \\
\text { ths. kWh/ } \% \text { of all } \\
\text { electricity consumed }\end{array}$ & $\begin{array}{c}10.425 / \\
84.7\end{array}$ & $\begin{array}{c}10.869 / \\
90.2\end{array}$ & $\begin{array}{c}10.960 / \\
91.4\end{array}$ & 97.5 \\
\hline $\begin{array}{c}\text { Electric intensity of } \\
\text { commercial products, } \\
\mathrm{kWh} / \text { ths. RUB }\end{array}$ & 3.49 & 3.17 & 3.10 & 88.8 \\
\hline $\begin{array}{l}\text { Costs for electric and } \\
\text { heat energy, ths. RUB }\end{array}$ & 63.029.0 & 66.151 .8 & 74.723.1 & 118.6 \\
\hline $\begin{array}{c}\text { Share of energy costs } \\
\text { in the food marketing } \\
\text { bill, } \%\end{array}$ & 1.78 & 1.74 & 1.93 & - \\
\hline
\end{tabular}

Table 3. Volume of production and consumption of electric and heat energy by the Dmitrogorsk meat-processing plant

For the period 2017-2019, the physical volume of meat production increased by $5.4 \%$, and the electric consumption of production decreased by $11.2 \%$. However, due to a rise in natural gas price for the target period by almost $20 \%$, the cost of energy resources increased from $63 \mathrm{mln}$. RUB to $74.7 \mathrm{mln}$. RUB, and their share in the cost of commercial products increased by $1.5 \%$. 
The total amount of capital investments incurred for the construction of the power gen-set is $177.1 \mathrm{mln}$. RUB, of which $116.4 \mathrm{mln}$. RUB accounts for electric power and $60.7 \mathrm{mln}$. RUB - for heat and power. In the structure of capital investments, the largest proportion of costs $(68 \%)$ falls on equipment and communications.

The breakdown of costs for the power gen-set to generate electric thermal energy suggest that the largest share falls on the fuel component - natural gas (for electricity - $53.6 \%$; thermal energy - 48.05), significant costs for depreciation, repair and maintenance of the power gen-set (Table 4).

Table 4. Breakdown of costs for the production of electrical and heat energy by the power gen-set at the AgroPromkomplektatsiya Holding

\begin{tabular}{|c|c|c|c|c|}
\hline \multirow{2}{*}{ Cost item } & \multicolumn{2}{|c|}{ Electricity } & \multicolumn{2}{c|}{ Heat } \\
\cline { 2 - 5 } & ths. RUB & $\begin{array}{c}\text { \% of the } \\
\text { total } \\
\text { amount }\end{array}$ & ths. RUB & $\begin{array}{c}\text { \% of the } \\
\text { total } \\
\text { amount }\end{array}$ \\
\hline Salary & 5.360 .1 & 8.5 & 2.862 .2 & 7.6 \\
\hline Charge on payroll & 1.560 .1 & 2.5 & 846.1 & 2.2 \\
\hline Cost of natural gas & 34.024 .6 & 53.6 & 18.112 .8 & 48.0 \\
\hline $\begin{array}{c}\text { Repair and } \\
\text { maintenance } \\
\text { expenses }\end{array}$ & 8.904 .6 & 14.1 & 4.725 .1 & 12.5 \\
\hline Wear & 11.641 .4 & 18.4 & 6.070 .8 & 16.1 \\
\hline Other expenses & 1.824 .4 & 2.9 & 5.152 .0 & 13.6 \\
\hline Total & 63.315 .2 & 100.0 & 37.769 .0 & 100.0 \\
\hline
\end{tabular}

It is interesting to compare the cost of producing a unit of energy with established tariffs for electricity and heat. With the costs and volumes of production of electric and heat energy by the power gen-set in 2019 , the cost of $1 \mathrm{kWh}$ was 3.24 RUB, and $1 \mathrm{Gcal}-1,682.6$ RUB, respectively (Table 5).

Table 5. Comparative assessment of the cost of production of electrical and thermal energy by the power gen-set and tariffs for electrical and thermal energy

\begin{tabular}{|c|c|c|}
\hline Index & $\begin{array}{c}\text { Electrical } \\
\text { energy, } \\
\text { RUB/kWh }\end{array}$ & $\begin{array}{c}\text { Thermal } \\
\text { energy, } \\
\text { RUB/Gcal }\end{array}$ \\
\hline Relative capital investment & 5.95 & 2.259 .0 \\
\hline Prime cost & 3.34 & 1.682 .4 \\
\hline Tariff & 6.41 & 2.304 .8 \\
\hline In \% prime cost to tariff & 50.5 & 73.0 \\
\hline
\end{tabular}

Table 6. Indicators for the feasibility of using local system of energy supply to the AgroPromkomplektatsiya facilities

\begin{tabular}{|c|c|c|}
\hline Index & $\begin{array}{c}\text { Electrical } \\
\text { energy }\end{array}$ & $\begin{array}{c}\text { Thermal } \\
\text { energy }\end{array}$ \\
\hline Cost limit & $\begin{array}{c}5.52 \\
\text { RUB/kWh }\end{array}$ & $\begin{array}{c}1,965.1 \\
\text { RUB/Gcal }\end{array}$ \\
\hline Actual cost & $\begin{array}{c}3.34 \\
\text { RUB/kWh }\end{array}$ & $\begin{array}{c}1,682.4 \\
\text { RUB/Gcal }\end{array}$ \\
\hline $\begin{array}{c}\text { Actual cost-performance } \\
\text { ratio of investments }\end{array}$ & 0.53 & 0.28 \\
\hline $\begin{array}{c}\text { In \% to the standard value } \\
\text { (Es =0.15) }\end{array}$ & 353.3 & 186.7 \\
\hline
\end{tabular}

The data in Table 5 indicate that the cost of electricity production by the power gen-set is 2 times lower than the current tariff. The cost of heat energy is approximately $30 \%$ lower in relation to the current tariff.

How efficient is the local power supply system? To answer the question posed, the authors use the previously obtained conditions (3) and (4) and perform all necessary calculations. The results obtained are summarized in Table 6.

The estimates confirm the economic feasibility of using a local power supply system by the AgroPromkomplektatsiya Holding in the form of a power gen-set based on the Jenbacher gas enginegenerators.

The methods proposed are suitable for determining and evaluating economic indicators, making effective decisions on the possibility of using local energy sources, including alternative and renewable, for power supply to agricultural facilities.

Based on the best operating practices and indicators of the above example of local power supply use, the following technical and economic advantages of gas engine-generators used as mini-HPP should be highlighted:

- high reliability of GEG equipment in operation, extreme simplicity of design, in fact it is an internal combustion engine, natural gas or biogas of appropriate quality is used as fuel;

- uncomplicated operation process. There is no need to attract highly qualified experts to service gas enginegenerators; with the proper degree of automation and digitalization, remote control of the installation is possible;

- significant technical resource. The operating time before the first major overhaul is 63 thousand motorcycle hours, 4 major overhauls are allowed;

- the ability to operate in any conditions, the equipment is renowned for stable performance regardless of the ambient temperature; obtaining two types of energy - electrical and thermal, which allows the use of the generator as a mini-HPP;

- average service life, serviceable operation of the equipment for 30 years.

\section{Conclusions}

Intensive re-equipment of agro-industrial production based on the use of modern technologies and innovations in the energy sector presupposes reliable and sustainable energy supply. The latter can be accomplished through centralized power supply from central stations, simultaneously involving both local sources and energy supply systems for agricultural facilities. This is reasonably necessary due to the poor condition of rural energy grids, an increase in tariffs for energy resources, and a brisk growth of alternative and renewable energy sources. The proposed methods for assessing energy supply options for agro-industrial production and rural infrastructure facilities allows for an economically objective assessment of energy supply systems and, on this basis, to make an effective engineering and technical 
decision on the method of energy supply to an agricultural enterprise.

\section{References}

1. T.A. Azimov, L.Yu. Beznoschuk, Alternative energy sources in Russia as a replacement for the energy of oil products. Text: direct, electronic, Young sci., 10(144), 180-182 (2017)

2. P.P. Bezrukikh, D.S. Strebkov, Renewable energy: strategy, resources, technology (GNU VIESH, Moscow, 2005), 187 p.

3. A.E. Boyarintsev, N.M. Semenenko, Alternative energy sources, Sci.-method. electr. J. "Concept", 25, 106-110 (2015)

4. V.T. Vodyannikov, Economic foundations for the development of rural energy, Monograph (Moscow State Agroeng. Univ. Named after V.P. Goryachkin, Moscow, 2012), 184 p.

5. V.T. Vodyannikov, N.A. Sereda, O.N. Kukharev et. al., Economic assessment of design solutions and agroengineering, Ed. by V.T. Vodyannikov, Textbook (Lan, St. Petersburg, 2019), 436 p.
6. V.D. Popov, V.N. Sudachenko, N.I. Shimchenko, Experience of the Leningrad Region on Energy Saving in Agricultural Production (GNU "Rosinformagrotech", Moscow, 2007), 64 p.

7. N.I. Proca, A.S. Volchenkova, Comparative analysis of the level of labor productivity in the agricultural sector of the economy, Bull. of the Oryol State Univ., 2(35), 106-112 (2012)

8. V.N. Sudachenko, Preferential tariff for electricity is an important incentive for the efficient use of energy resources, Int. mag. Agricult. News, 3(70), 10 (2007)

9. D.S. Strebkov, D.A. Tikhomirov, A.V. Tikhomirov, Indicators of consumption of fuel and energy resources in agriculture and energy intensity of agricultural production, their forecast for the period up to 2030, VNIIMZH Bull., 4(32), 4-12 (2018)

10. B.A. Chernyakov, The current state of the US agricultural sector, In: The agricultural sector and food security of the United States in the early 21 century (pp. 10-36) (Moscow, 2015) 